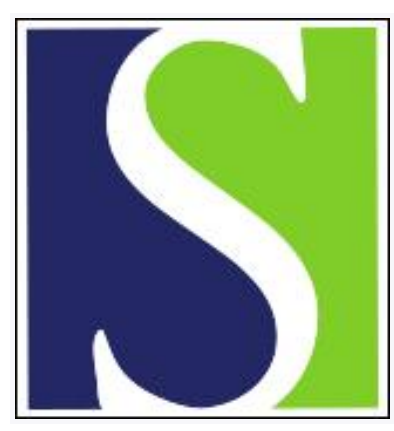

Scand J Work Environ Health 1997;23(5):359-363

https://doi.org/10.5271/sjweh.232

Issue date: Oct 1997

Lead concentrations in human plasma, urine and whole blood

by Bergdahl IA, Schütz A, Gerhardsson L, Jensen A, Skerfving S

Key terms: biological monitoring; inductively coupled plasma mass spectrometry; serum

This article in PubMed: www.ncbi.nlm.nih.gov/pubmed/9403466

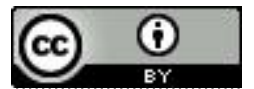




\title{
Lead concentrations in human plasma, urine and whole blood
}

\author{
by Ingvar A Bergdahl, MSc, ${ }^{1}$ Andrejs Schütz, PhD, ${ }^{1}$ Lars Gerhardsson, MD, ${ }^{1}$ Anker Jensen, MD, ${ }^{2}$ \\ Staffan Skerfving, $M D^{1}$
}

\begin{abstract}
Bergdahl IA, Schütz A, Gerhardsson L, Jensen A, Skerfving S. Lead concentrations in human plasma, urine and whole blood. Scand J Work Environ Health 1997;23(5):359-63.

Objectives Blood-lead levels (B-Pb), and to some extent urinary lead (U-Pb), are the most employed measures of lead exposure and risk. However, the small fraction of lead present in plasma (usually below $1 \%$ of that in blood) is probably more relevant to lead exposure and toxicity. Nevertheless, the lead content of plasma lead $(\mathrm{P}-\mathrm{Pb})$ has only seldom been used, mainly due to analytical limitations, which have now been overcome. We examined $\mathrm{P}-\mathrm{Pb}$ in occupationally exposed subjects, as well as its relationship with $\mathrm{B}-\mathrm{Pb}$ and $\mathrm{U}-\mathrm{Pb}$.

Methods Blood samples were obtained from 145 male workers, 110 of whom were employed in lead work After a simple dilution of plasma, $\mathrm{P}-\mathrm{Pb}$ was determined by inductively coupled plasma mass spectrometry. The detection limit was $0.04 \mu \mathrm{g} / \mathrm{l}$, and the imprecision was $5 \%$.

Results The lead concentration ranges were $0.20-37 \mu \mathrm{g} / 1$ for $\mathrm{P}-\mathrm{Pb}, 0.9-176 \mu \mathrm{g} / \mathrm{l}$ (density adjusted) for $\mathrm{U}-\mathrm{Pb}$, and $9-930 \mu \mathrm{g} / \mathrm{l}$ for $\mathrm{B}-\mathrm{Pb}$. A close exponential relation was obtained between $\mathrm{B}-\mathrm{Pb}$ and $\mathrm{P}-\mathrm{Pb}$. When $\mathrm{B}-\mathrm{Pb}$ was plotted versus $\log \mathrm{P}-\mathrm{Pb}$, a straight $\operatorname{line}(\log \mathrm{P}-\mathrm{Pb}=0.00225 \cdot \mathrm{B}-\mathrm{Pb}-0.58 ; \mathrm{r}=0.97)$ was obtained. Both the relation between $\mathrm{U}-\mathrm{Pb}$ and $\mathrm{P}-\mathrm{Pb}$ and that between $\mathrm{U}-\mathrm{Pb}$ and $\mathrm{B}-\mathrm{Pb}$ showed a large scattering $(\mathrm{r}=0.78$ in both cases). The relation to $\mathrm{B}-\mathrm{Pb}$ appeared to be exponential, while that to $\mathrm{P}-\mathrm{Pb}$ appeared to be linear.

Conclusions The low detection limit and good precision of $\mathrm{P}-\mathrm{Pb}$ determinations make it possible to use $\mathrm{P}-\mathrm{Pb}$ in assessments of lead exposure and risk. Furthermore, in relative terms, $\mathrm{P}-\mathrm{Pb}$ is a more sensitive measure than $\mathrm{B}-\mathrm{Pb}$, especially at high lead levels. This development is of importance for studies of exposure, possibly also for studies of risks.
\end{abstract}

Key terms biological monitoring, inductively coupled plasma mass spectrometry, serum.

The concentration of lead in human plasma $(\mathrm{P}-\mathrm{Pb})$ and serum $(\mathrm{S}-\mathrm{Pb})$ has been shown to be very low, usually less than $1 \%$ of that in whole blood (B-Pb), but with the percentage increasing with rising lead levels $(1,2)$. The small fraction in plasma may be the most relevant for distribution to, for example, the bone marrow, kidney, nervous system, and fetus, and thus of greatest toxicologic interest. Because the $\mathrm{P}-\mathrm{Pb}$ is so low, accurate determination has been difficult, and thus $\mathrm{B}-\mathrm{Pb}$ is the most widely employed measure of lead exposure and risk.

Hence, if the analytical limitations could be overcome, $\mathrm{P}-\mathrm{Pb}$ may be a better measure of lead exposure and risk than $\mathrm{B}-\mathrm{Pb}$. Another potential measure of the metabolically most relevant part of lead in blood may be urinary lead (U-Pb), which reflects lead from plasma, excreted through the kidneys. There is little information on the relationship between $\mathrm{U}-\mathrm{Pb}$ and $\mathrm{P}-\mathrm{Pb}$.
Numerous studies of lead exposure and effect toxicity have been based on $\mathrm{B}-\mathrm{Pb}$. If the relation between $\mathrm{B}-\mathrm{Pb}$ and $\mathrm{P}-\mathrm{Pb}$ were known, $\mathrm{P}-\mathrm{Pb}$ could be estimated from the old $\mathrm{B}-\mathrm{Pb}$ data.

Recently, we presented a new method for determining $\mathrm{P}-\mathrm{Pb}$ using inductively coupled plasma mass spectrometry (ICP-MS)(2). The method had a precision superior to that of previous ones, and $\mathrm{P}-\mathrm{Pb}$ was proposed as a means of biologically monitoring lead exposure and risk. However, the number of samples was small, and the lead levels were relatively modest; thus, the relation between $\mathrm{B}-\mathrm{Pb}$ and $\mathrm{P}-\mathrm{Pb}$ was not fully revealed.

The strong accumulation of lead in erythrocytes is probably attributable to the binding of lead to $\delta$-aminolevulinic acid dehydratase (ALAD) $(3,4)$. Human ALAD has been shown to be a polymorphic enzyme, with 2 alleles ( $\mathrm{ALAD}^{1}$ and $\mathrm{ALAD}^{2}$ ) responsible for 3 distinct

1 Department of Occupational and Environmental Medicine, Lund University, Lund, Sweden.

2 BAD Gesundheitsvorsorge und Sicherheitstechnik GmbH, Zentrum Braunschweig, Braunschweig-Bienrode, Germany.

Reprint requests to: Mr Ingvar A Bergdahl, Department of Occupational and Environmental Medicine, Lund University, S22185 Lund, Sweden. 
charge isozyme phenotypes: ALAD 1-1, ALAD 1-2, and ALAD 2-2 (5). In some studies of lead-exposed persons, carriers of the $\mathrm{ALAD}^{2}$ allele have had higher B-Pb levels than homozygotes for the $\mathrm{ALAD}^{\prime}$ allele $(6,7)$, and it has been hypothesized that this occurrence reflects a tighter binding of lead to the ALAD2 subunit than to the ALAD1 subunit (8). In that case, the $\mathrm{B}-\mathrm{Pb}: \mathrm{P}-\mathrm{Pb}$ ratio should be higher among carriers of the $\mathrm{ALAD}^{2}$ allele compared with homozygotes for the $\mathrm{ALAD}^{\perp}$ allele.

The present study was undertaken to assess the $\mathrm{B}-\mathrm{Pb}: \mathrm{P}-\mathrm{Pb}$ and $\mathrm{U}-\mathrm{Pb}: \mathrm{P}-\mathrm{Pb}$ relationships in a larger group, and at higher lead levels than in our former study. Furthermore, a small study was made of the influence of the ALAD polymorphism on the $\mathrm{B}-\mathrm{Pb}: \mathrm{P}-\mathrm{Pb}$ relation.

\section{Subjects and methods}

\section{Subjects}

Samples were obtained from male workers in 3 workplaces. There were 20 workers (all active) from a German secondary lead smelter, 90 workers [71 active, 19 retired (period of retirement: median 6, range $1-14$ years)] from a Swedish secondary lead smelter and a reference group of 35 workers [ 27 active, 8 retired (median 1 , range $0-4$ years after the end of employment)] from a Swedish mechanical workshop with no occupational exposure to lead. Two retired workers ( 1 exposed and 1 referent) were excluded from the study due to insufficient volumes of urine or plasma for the lead determination.

The Swedish workers have been described elsewhere (9). The German workers had a median age of 40 (range 25-54) years and a median employment time of 15 (range 3-38) years. For the German workers, only P-Pb and $\mathrm{B}-\mathrm{Pb}$ were determined. For the Swedish workers, also $\mathrm{U}-\mathrm{Pb}$, urinary creatinine and density, serum albumin and ALAD phenotype were determined.

\section{Lead determinations}

In all the workers, $\mathrm{P}-\mathrm{Pb}$ was determined by ICP-MS after dilution $1+4$ with a solution containing ammonia (0.04 mol/l), Triton X-100 (polyethylene glycol p-isooctylphenyl ether) (100 mg/l), and disodium ethylendiamminetetraacetic dihydrate $\left(\mathrm{Na}_{2}\right.$ EDTA) $(200 \mathrm{mg} / \mathrm{l})$, according to a previously described method (2). The imprecision, calculated as the coefficient of variation for duplicate determinations, was $5 \%$, and the limit of detection was $0.04 \mu \mathrm{g} / \mathrm{l}$. The limit of detection was calculated as 3 times the standard deviation for a plasma sample low in lead $(0.16 \mu \mathrm{g} / 1)$, analyzed 24 times in 8 days. As quality control, lyophilized serum (Seronorm batch 010017, Nycomed AS, Oslo, Norway) and whole blood (Seronorm batch 205052) were incorporated into the an- alytical series. Our serum results averaged 2.5 (SD 0.2 , $\mathrm{N}=9) \mu \mathrm{g} / \mathrm{l}$, which is identical to previously obtained results (2). No certified or recommended value exists for the lead concentration in the lyophilized serum sample. Our whole-blood results averaged $31.7(\mathrm{SD} 0.9, \mathrm{~N}=14)$ $\mu \mathrm{g} / \mathrm{l}$, while the recommended value was 35 (range 31 41) $\mu g / l$.

$\mathrm{B}-\mathrm{Pb}$ and $\mathrm{U}-\mathrm{Pb}$ were determined by electrothermal atomization atomic absorption spectrometry. The analytical methods have been described in detail elsewhere (9). For $\mathrm{B}-\mathrm{Pb}$ the coefficient of variation for sample duplicates was $8 \%$ in the range $9-99 \mu \mathrm{g} / \mathrm{l}$, and $4 \%$ in the range $100-930 \mu \mathrm{g} / \mathrm{l}$. Lyophilized whole blood was used as quality control samples. In the analysis of the Swedish samples, Seronorm batch 905 was analyzed, giving an average of 384 (SD 19, $\mathrm{N}=27$ ) $\mu \mathrm{g} / 1$, as compared with the 400 (SD 24) $\mu \mathrm{g} / \mathrm{l}$ recommended. In the analysis of the German samples, Seronorm batch 203056 was analyzed, resulting in an average of 396 (range 390-403, $\mathrm{N}=2$ ) $\mu \mathrm{g} / \mathrm{l}$, as compared with the 383 (range $361-396$ ) $\mu \mathrm{g} / \mathrm{l}$ recommended. For $\mathrm{U}-\mathrm{Pb}$, the coefficient of variation for sample duplicates was $2 \%$ in the range $2-$ $20 \mu \mathrm{g} / \mathrm{I}$ and $1 \%$ in the range $21-110 \mu \mathrm{g} / \mathrm{l}$. Lyophilized urine (Seronorm batch 009024) was used as a quality control sample. Our results averaged 101 (SD 4.5, $\mathrm{N}=12) \mu \mathrm{g} / \mathrm{l}$, compared with 83 and $97 \mu \mathrm{g} / \mathrm{l}$ in 2 other laboratories.

A method based on polymerase chain reaction (PCR) was used to determine $\mathrm{ALAD}^{1}$ and $\mathrm{ALAD}^{2}$ alleles in small samples of heparinized blood (10). Serum albumin and urinary creatinine were determined by standard methods at the Department of Clinical Chemistry, University Hospital, Lund. For urinary creatinine, the coefficient of variation, calculated from duplicate determinations on different days, was $6 \%$. The urine density was determined by refractometry.

\section{Results}

The lead concentration medians and ranges for the leadexposed workers were $1.5(0.43-37) \mu \mathrm{g} / \mathrm{l}$ for $\mathrm{P}-\mathrm{Pb}, 10$ (2.0-176) $\mu \mathrm{g} / \mathrm{l}$ [adjusted for density: $10(1.7-50) \mu \mathrm{mol} /$ mol creatinine] for $\mathrm{U}-\mathrm{Pb}$, and $342(77$-930) $\mu \mathrm{g} / \mathrm{l}$ for B$\mathrm{Pb}$. For the referents the medians and ranges were 0.34 $(0.20-0.54) \mu \mathrm{g} / 1$ for $\mathrm{P}-\mathrm{Pb}, 2.2(0.9-4.8) \mu \mathrm{g} / \mathrm{1}$ for $\mathrm{U}-\mathrm{Pb}$ [adjusted for density: $2.3(0.86-3.9) \mu \mathrm{mol} / \mathrm{mol}$ creatinine], and $37(8-70) \mu \mathrm{g} / \mathrm{l}$ for $\mathrm{B}-\mathrm{Pb}$.

A plot of $\mathrm{B}-\mathrm{Pb}$ versus $\mathrm{P}-\mathrm{Pb}$ showed a close correlation, with an exponential shape (figure $1 \mathrm{~A}$ ). When $\mathrm{B}-\mathrm{Pb}$ was plotted versus $\log \mathrm{P}-\mathrm{Pb}$, a straight line with the equation $\log (\mathrm{P}-\mathrm{Pb})=0.00225 \cdot \mathrm{B}-\mathrm{Pb}-0.58$ and a correlation coefficient of $\mathrm{r}=0.97$ was obtained (figure $1 \mathrm{~B}$ ). Even the extreme point at a $\mathrm{P}-\mathrm{Pb}$ of $37 \mu \mathrm{g} / \mathrm{l}$ and $\mathrm{a} \mathrm{B-Pb}$ 
A

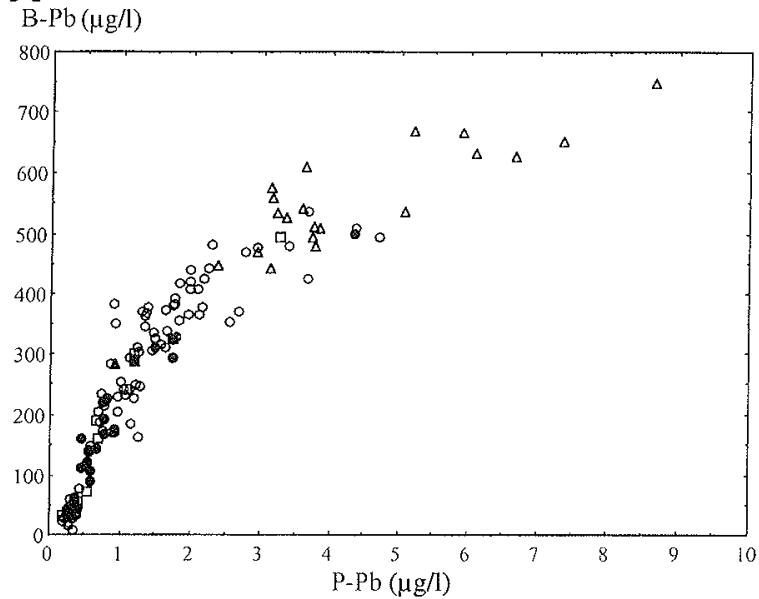

B

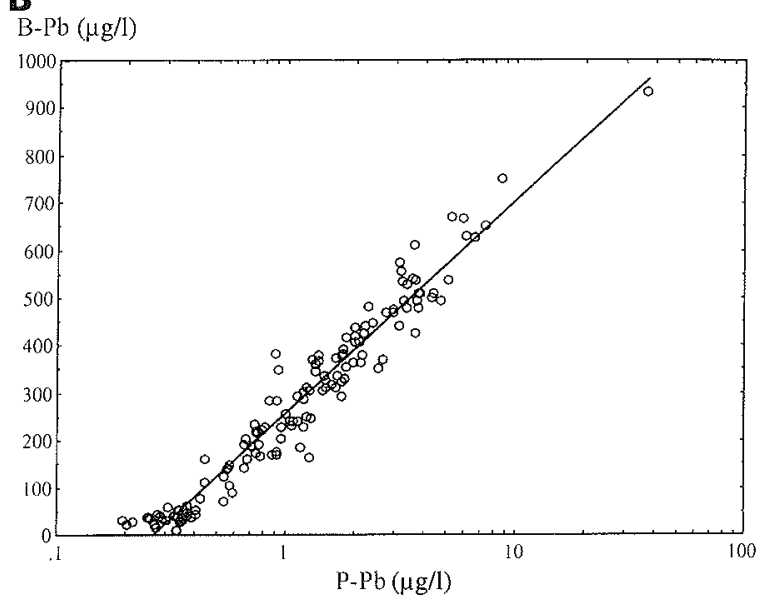

Figure 1. Relation between whole blood ( $\mathrm{B}-\mathrm{Pb}$ ) and plasma ( $\mathrm{P}-\mathrm{Pb}$ ) lead concentrations in 118 active (open symbols) and 25 retired (closed symbols) workers. Subjects with $\delta$-aminolevulinic acid dehydratase allele $A L A D^{2}$ are denoted with squares, homozygotes for the ALAD ${ }^{1}$ allele with circles, and subjects with unknown ALAD phenotype with triangles. The extreme point at a $\mathrm{P}-\mathrm{Pb}$ of $37 \mu \mathrm{g} / \mathrm{l}$ and a B-Pb of $930 \mu \mathrm{g} / \mathrm{l}$ has been omitted from figure $1 \mathrm{~A}$. In figure $1 \mathrm{~B}$, the $\mathrm{P}-\mathrm{Pb}$ has been logarithmically transformed, and the linear regression line $(\mathrm{B}-\mathrm{Pb}=444 \cdot \log \mathrm{P}-\mathrm{Pb}+257, \mathrm{r}=0.97$, corresponding to $\log \mathrm{P}-\mathrm{Pb}=0.00225 \cdot \mathrm{B}-\mathrm{Pb}-0.58$ ) is shown.

of $930 \mu \mathrm{g} / \mathrm{l}$ fit very well. The relation between $\mathrm{B}-\mathrm{Pb}$ and $\mathrm{P}-\mathrm{Pb}$ does not run through origin; the intercept on the $\mathrm{P}$ $\mathrm{Pb}$ axis is approximately $0.2 \mu \mathrm{g} / 1$.

The $\mathrm{B}-\mathrm{Pb}: \mathrm{P}-\mathrm{Pb}$ ratio for the 18 retired lead workers did not show even a tendency to differ from that of the active workers in the $\mathrm{B}-\mathrm{Pb}: \mathrm{P}-\mathrm{Pb}$ plot, nor did the 17 carriers of the $\mathrm{ALAD}^{2}$ allele differ from homozygotes for the $\mathrm{ALAD}^{1}$ allele (figure $1 \mathrm{~A}$ ).

There was a correlation between $\mathrm{U}-\mathrm{Pb}$ and $\mathrm{B}-\mathrm{Pb}$, but with a large variation $(\mathrm{r}=0.78$, when the extreme value at a U-Pb of $176 \mu \mathrm{g} / \mathrm{l}$ was excluded, figure 2). The

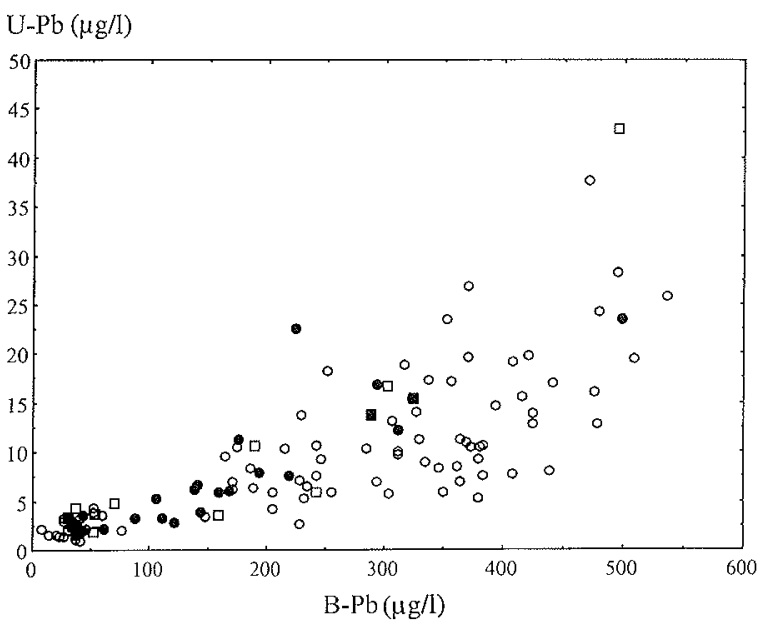

Figure 2. Relation between urine (U-Pb, density adjusted) and whole blood (B-Pb) lead concentrations in 98 active (open symbols) and 25 retired (closed symbols) workers. Subjects with $\delta$-aminolevulinic acid dehydratase allele $A L A D^{2}$ are denoted with squares and homozygotes for the ALAD' allele with circles. The extreme point at a B-Pb of $930 \mu \mathrm{g} / \mathrm{l}$ and $\mathrm{a} \mathrm{U}-\mathrm{Pb}$ of $176 \mu \mathrm{g} / \mathrm{l}$ has been excluded. relation appeared to be exponential. A similarly scattered relation was found between $\mathrm{U}-\mathrm{Pb}$ and $\mathrm{P}-\mathrm{Pb}(\mathrm{r}=0.78$, when the extreme value at a U-Pb of $176 \mu \mathrm{g} / \mathrm{l}$ was excluded; figure 3 ). The relation did not appear to be exponential. In the multiple regression analysis, neither serum albumin ( $\mathrm{B}-\mathrm{Pb}: \mathrm{P}=0.2 ; \mathrm{P}-\mathrm{Pb}: \mathrm{P}=0.4$ ) nor age (B$\mathrm{Pb}: \mathrm{P}=0.4 ; \mathrm{P}-\mathrm{Pb}: \mathrm{P}=0.09$ ) significantly explained the variation in any of the correlations. No difference in the ratio between the U-Pb and $\mathrm{P}-\mathrm{Pb}$ could be found between the active and retired workers or between the carriers of the $\mathrm{ALAD}^{2}$ allele and homozygotes for the $\mathrm{ALAD}^{1}$ al-

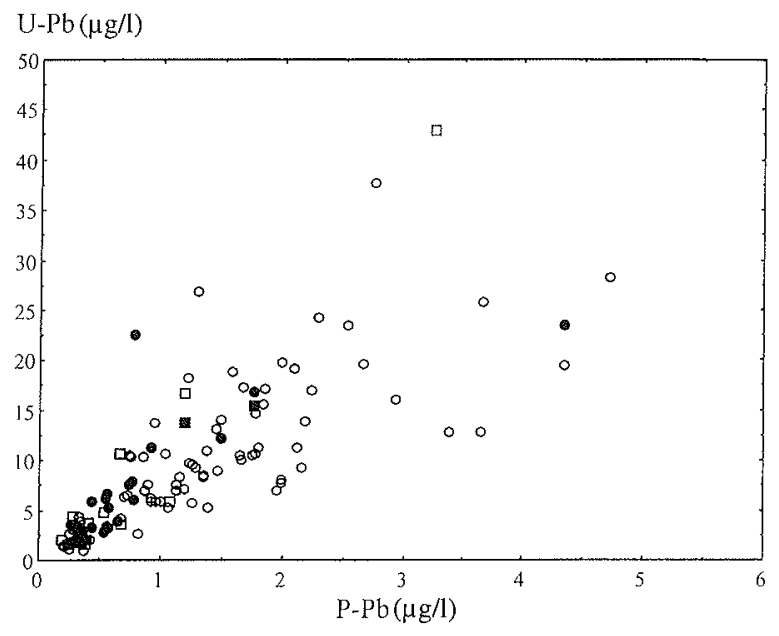

Figure 3. Relation between urine (U-Pb, density adjusted) and plasma (P-Pb) lead concentrations in 98 active (open symbols) and 25 retired (closed symbols) workers. Subjects with $\delta$-aminolevulinic acid dehydratase allele $A L A D^{2}$ are denoted with squares, homozygotes for the ALAD' allele with circles. The extreme point at a P-Pb of $37 \mu \mathrm{g} / \mathrm{l}$ and a $\mathrm{U}-\mathrm{Pb}$ of $176 \mu \mathrm{g} / \mathrm{l}$ has been excluded. 
lele. Similarly, no such difference was found in the ratio between $\mathrm{U}-\mathrm{Pb}$ and $\mathrm{B}-\mathrm{Pb}$.

\section{Discussion}

The present study clearly shows that the relation between $\mathrm{B}-\mathrm{Pb}$ and $\mathrm{P}-\mathrm{Pb}$ is exponential, even at high lead levels. In contrast, the relation between $\mathrm{U}-\mathrm{Pb}$ and $\mathrm{P}-\mathrm{Pb}$ seemed to be rectilinear, even though the scattering of the points was much larger than in the $\mathrm{B}-\mathrm{Pb}: \mathrm{P}-\mathrm{Pb}$ plot. The close association in the $\mathrm{B}-\mathrm{Pb}: \mathrm{P}-\mathrm{Pb}$ plot shows that the precision of $\mathrm{P}-\mathrm{Pb}$ determinations makes possible the use of $\mathrm{P}-\mathrm{Pb}$ in assessments of lead exposure and risks.

The relation between $\mathrm{U}-\mathrm{Pb}$ and $\mathrm{P}-\mathrm{Pb}$ was not stronger than that between $\mathrm{U}-\mathrm{Pb}$ and $\mathrm{B}-\mathrm{Pb}$. Some of the considerable variation may arise from difficulties in adjusting for urine dilution. However, both the density and creatinine (data not shown) adjustment gave similar scatterings of the points. On the other hand, such corrections for dilution may not be sufficient. For example, the circadian rhythm of lead excretion into urine may have influenced the results (11). However, there may also be a true interindividual variation in the excretion of lead in urine. We found that the interindividual variation in the $\mathrm{U}-\mathrm{Pb}: \mathrm{P}-\mathrm{Pb}$ relation could not be explained by the serum albumin concentration, which is of importance to the relative filtration of calcium into urine, neither did age explain a statistically significant part of the variation.

We were unable to find any ALAD-specific differences in the $\mathrm{B}-\mathrm{Pb}: \mathrm{P}-\mathrm{Pb}$ or $\mathrm{U}-\mathrm{Pb}: \mathrm{P}-\mathrm{Pb}$ ratios. Thus the ALAD-associated differences in $\mathrm{B}-\mathrm{Pb}$ previously observed (6-8) do not seem to be mediated by a difference in the degree of accumulation of lead in the erythrocytes.

In the $\mathrm{B}-\mathrm{Pb}: \mathrm{P}-\mathrm{Pb}$ plot, the intercept on the $\mathrm{P}-\mathrm{Pb}$ axis (at approximately $0.2 \mu \mathrm{g} / \mathrm{l}$ ) indicated a systematic error of unknown origin in the $\mathrm{P}-\mathrm{Pb}$ determination. A possible source was contamination of the blood-sampling tubes. However, several studies have shown that lead added to blood is rapidly taken up by the erythrocytes (12-16). Thus, when the plasma was separated, the $\mathrm{B}-\mathrm{Pb}$ and $\mathrm{P}-\mathrm{Pb}$ should have already reached an equilibrium. Systematic contamination of test tubes, pipette tips, and other such equipment may have introduced an error, even though no contamination sources have been identified. Furthermore, reagent blanks were subtracted. Although an analytical artifact seems to be the most probable explanation for the intercept, another possibility is that the $\mathrm{B}-\mathrm{Pb}: \mathrm{P}-\mathrm{Pb}$ relation is in fact not exponential, but sigmoidal at very low lead levels.

The $\mathrm{B}-\mathrm{Pb}: \mathrm{P}-\mathrm{Pb}$ relation was similar to the results reported in a smaller study, in which a relation $\log$ $\mathrm{P}-\mathrm{Pb}=0.00277 \cdot \mathrm{B}-\mathrm{Pb}-0.77$ was obtained (2), which can be compared with the $\log \mathrm{P}-\mathrm{Pb}=0.00225 \cdot \mathrm{B}-\mathrm{Pb}-$
0.58 obtained in our present study. Our study showed in addition that the relation was exponential even at high lead levels. This finding is in accordance with the results of other reports $(1,13)$.

As discussed in a previous paper (2), possible mechanisms behind the nonlinear $\mathrm{B}-\mathrm{Pb}: \mathrm{P}-\mathrm{Pb}$ relation may be a saturation of lead-binding sites on certain proteins in erythrocytes [most likely $\operatorname{ALAD}(3,4)$ ], lead-inflicted hemolysis resulting in the release of lead from erythrocytes, or a lead-induced increase of lead-binding proteins in plasma (2).

Previous studies have indicated a considerable scattering of the points in $\mathrm{B}-\mathrm{Pb}: \mathrm{P}-\mathrm{Pb}$ or $\mathrm{B}-\mathrm{Pb}: \mathrm{S}-\mathrm{Pb}$ plots, probably due to analytical limitations. At first glance at the present $\mathrm{B}-\mathrm{Pb}: \mathrm{P}-\mathrm{Pb}$ plot, the interindividual difference seems to be very limited. However, for samples with the same $\mathrm{B}-\mathrm{Pb}$, a variation in $\mathrm{P}-\mathrm{Pb}$ with a factor of 2 is not uncommon. The imprecision of the $\mathrm{P}-\mathrm{Pb}$ determinations was only $5 \%$, and it does not seem to account for the variation. However, the variation may, to some extent, be explained by a similar imprecision in the B-Pb determination $(4 \%)$, which had a stronger impact, due to the exponential relation. Still, there is a possibility of considerable variation between individuals, constantly or varying over time. The current exposure did not seem to explain the variation, as retired workers did not differ from active ones.

An interindividual variation may be important from a health point of view; a worker obtaining a relatively higher $\mathrm{P}-\mathrm{Pb}$ at a certain exposure may run a risk that is not reflected by the $\mathrm{B}-\mathrm{Pb}$. Such an interindividual variation in the $\mathrm{B}-\mathrm{Pb}: \mathrm{P}-\mathrm{Pb}$ relation may be the background of the findings of Hirata et al (17), who reported closer associations for $\mathrm{P}-\mathrm{Pb}$ than for $\mathrm{B}-\mathrm{Pb}$, when correlated to $\mathrm{U}-\mathrm{Pb}$, urinary coproporphyrin, and $\delta$-aminolevulinic acid in urine and plasma. However, due to the exponential $\mathrm{B}-\mathrm{Pb}: \mathrm{P}-\mathrm{Pb}$ relation, the $\mathrm{P}-\mathrm{Pb}$ range was larger than the $\mathrm{B}-\mathrm{Pb}$ range, and $\mathrm{P}-\mathrm{Pb}$ had a binomial distribution, while $\mathrm{B}-\mathrm{Pb}$ had a more normal one. This situation may have favored $\mathrm{P}-\mathrm{Pb}$ when the coefficients of variation were compared. Hence this important issue is still open.

The possibility to determine $\mathrm{P}-\mathrm{Pb}$ with good precision urges lead toxicologists to determine $\mathrm{P}-\mathrm{Pb}$ in surveys of lead exposure and health effects. $\mathrm{P}-\mathrm{Pb}$ is, in relative terms, a more sensitive measure than $\mathrm{B}-\mathrm{Pb}$, especially at high lead levels where a relatively small increase in $\mathrm{B}-\mathrm{Pb}$ corresponds to a considerable rise in $\mathrm{P}-\mathrm{Pb}$. For example, an increase in $\mathrm{B}-\mathrm{Pb}$ from 500 to 600 to $700 \mu \mathrm{g} / \mathrm{l}$ corresponds to an increase in $\mathrm{P}-\mathrm{Pb}$ from 3.5 to 6 to $10 \mu \mathrm{g} / \mathrm{l}$, respectively.

The sample preparation used in our determinations of $\mathrm{P}-\mathrm{Pb}$ was simple and thereby minimized the risk of contamination, but access to the advanced technique of ICP-MS may be necessary to obtain accurate results. Another problem with obtaining good accuracy in the 
$\mathrm{P}-\mathrm{Pb}$ determinations is that no quality assurance programs for $\mathrm{P}-\mathrm{Pb}$ exist as yet. At present, one way to gain reasonable control of the accuracy is to determine $\mathrm{B}-\mathrm{Pb}$ (under careful quality control) and $\mathrm{P}-\mathrm{Pb}$ in several blood samples with different lead levels and check that a reasonably close correlation is achieved.

\section{Acknowledgments}

We thank the participating workers for leaving samples, Anders Ekholm for his skillful technical assistance, and Dr Robert J Desnick and Dr James G Wetmur for determining the ALAD alleles.

This work was financially supported by the Swedish Work Environment Fund, the Swedish Council for Planning and Coordination of Research, the National Swedish Environment Protection Agency, and the Medical Faculty of the Lund University.

\section{References}

1. Desilva PE. Determination of lead in plasma and studies on its relationship to lead in erythrocytes. Br J Ind Med 1981;38: 209-17.

2. Schütz A, Bergdahl IA, Ekholm A, Skerfving S. Measurement by ICP-MS of lead in plasma and whole blood of lead workers and controls. Occup Environ Med 1996;53:736-40.

3. Sakai T, Yanagihara S, Kunugi Y, Ushio K. Relationships between distribution of lead in erythrocytes in vivo and in vitro and inhibition of ALA-D. Br J Ind Med 1982;39:382-7.

4. Bergdahl IA, Schütz A, Grubb A. Application of liquid chromatography-inductively coupled plasma mass spectrometry to the study of protein-bound lead in human erythrocytes. J Anal At Spectrom 1996;11:735-8.

5. Battistuzzi G, Petrucci R, Silvagni L, Urbani FR, Caiola S. $\delta$-aminolevulinate dehydrase: a new genetic polymorphism in man. Ann Hum Genet 1981;45:223-229.

6. Astrin KH, Bishop DF, Wetmur JG, Kaul B, Davidow B, Desnick RJ. $\delta$-aminolevulinic acid dehydratase isozymes and lead toxicity. Ann NY Acad Sci 1987;514:23-39.

7. Wetmur JG, Lehnert G, Desnick RJ. The $\delta$-aminolevulinate dehydratase polymorphism: higher blood lead levels in lead workers and environmentally exposed children with the $1-2$ and 2-2 isozymes. Environ Res 1991;56:109-19.

8. Wetmur JG. Influence of the common human $\delta$-aminolevulinate dehydratase polymorphism on lead body burden. Environ Health Perspect 1994;102 suppl 3:215-9.

9. Börjesson J, Gerhardsson L, Schütz A, Mattsson S, Skerfving $\mathrm{S}$, Österberg $\mathrm{K}$. In vivo measurements of lead in fingerbone in active and retired lead smelters. Int Arch Occup Environ Health 1997;69:97-105.

10. Wetmur JG, Kaya AH, Plewinska M, Desnick RJ. Molecular characterization of the human $\delta$-aminolevulinate dehydratase $2\left(\right.$ ALAD $^{2}$ ) allele: implications for molecular screening of individuals for genetic susceptibility to lead poisoning. Am J Hum Genet 1991;49:757-63.

11. Araki S, Murata K, Yokoyama K, Yanagihara S, Niinuma $Y$, Yamamoto R, et al. Circadian rhythms in the urinary excretion of metal and organic substances in "healthy" men. Arch Environ Health 1983;38:360-6.

12. Clarkson TW, Kench JE. Uptake of lead by human erythrocytes in vitro. Biochemistry 1958:69:432-9.

13. Manton WI, Cook JD. High accuracy (stable isotope dilution) measurements of lead in serum and cerebrospinal fluid. $\mathrm{Br} J$ Ind Med 1984;41:313-9.

14. Campbell BC, Meredith PA, Moore MA, Watson WS. Kinetics of lead following intravenous administration in man. Toxicol Lett 1984;21:231-5.

15. Barton JC. Retention of radiolead by human erythrocytes in vitro. Toxicol Appl Pharmacol 1989;99:314-22.

16. Simons $T$. Lead transport and binding by human erythrocytes in vitro. Pflügers Arch 1993;423:307-13.

17. Hirata M, Yoshida T, Miyajima K, Kosaka H, Tabuchi T. Correlation between lead in plasma and other indicators of lead exposure among lead-exposed workers Int Arch Occup Environ Health 1995;68:58—63.

Received for publication: 16 October 1996 